\author{
Marcin Łysko \\ Uniwersytet w Białymstoku \\ e-mail: marcin.lysko@uwb.edu.pl
}

ORCID 0000-0002-2789-4679

DOI: $10.15290 / \mathrm{mhi} .2018 .17 .01 .11$

\title{
Ewolucja polskiego systemu prawa wykroczeń w XX w.
}

\begin{abstract}
Abstrakt
W momencie odzyskania przez państwo polskie niepodległości w listopadzie $1918 \mathrm{r}$. na jego obszarze obowiązywały regulacje byłych państw zaborczych, które reprezentowały trzy dominujące w ówczesnej Europie systemy prawa wykroczeń: francuski, austriacki i niemiecki. W ramach prowadzonych w Polsce międzywojennej prac nad stworzeniem jednolitego systemu prawa wykroczeń przyjęto rozwiązania zbliżone do wzorca niemieckiego. Pochodząca z 1928 r. kodyfikacja postępowania karno-administracyjnego poddawała wykroczenia orzecznictwu organów administracji państwowej, aczkolwiek przewidywała kontrolę sądową tego orzecznictwa. Jednolity system polskiego prawa wykroczeń uzupełniała wydana w $1932 \mathrm{r}$. kodyfikacja materialnego prawa wykroczeń, która przewidywała typowo represyjne kary aresztu zasadniczego i grzywny.

Rządzący Polską po II wojnie światowej komuniści stworzyli w 1951 r. zupełnie nowy na tle standardów europejskich model orzecznictwa w sprawach o wykroczenia. Rozstrzyganie spraw o wykroczenia powierzono organom kolegialnym orzekającym z udziałem czynnika społecznego. Wprawdzie postępowanie przed kolegiami zostało ukształtowane na podstawie procedury sądowej, lecz wzorem wywodzącego się Austrii modelu administracyjnego wprowadzono odwołanie do kolegium drugiej instancji. W miejsce kary aresztu przewidziano socjalistyczną karę pracy poprawczej, która przetrwała do $1958 \mathrm{r}$.

W 1958 r. kolegia zyskały prawo wymierzenia kary aresztu zasadniczego za niektóre poważniejsze wykroczenia, skutkiem czego było częściowe przywrócenie sądowej kontroli orzecznictwa karno-administracyjnego. Kolejnym wyrazem tendencji stopniowego odchodzenia od modelu administracyjnego była uchwalona w 1966 r. ustawa o przekazaniu niektórych drobnych przestępstw jako wykroczeń do orzecznictwa
\end{abstract}


karno-administracyjnego. Ustawa zapoczątkowała trwający do dnia dzisiejszego proces podziału czynów kryminalnych na przestępstwa i wykroczenia w zależności od wartości przedmiotu lub wysokości szkody. Przeprowadzona w 1971 r. kompleksowa kodyfikacja prawa wykroczeń kontynuowała proces dalszego wzbogacanie prawa wykroczeń instytucjami prawa karnego i procedury karnej. Jednakże pod względem ustrojowym system polskiego prawa wykroczeń posiadał cechy typowe dla modelu administracyjnego.

Dopiero upadek systemu komunistycznego umożliwił przeprowadzenie daleko idących zmian modelowych, które w pełni dopasowały orzecznictwo w sprawach o wykroczenia do standardów międzynarodowych. Przeprowadzona w 1990 r. reforma nadała kolegiom charakter quasi-sądów społecznych, funkcjonujących przy sądach karnych najniższego szczebla. Konsekwencją powiązania kolegiów z systemem sądów powszechnych było całkowite poddanie orzecznictwa w sprawach o wykroczenia kontroli sądowej. W 2001 r. nastąpiła likwidacja kolegiów, skutkiem czego było powierzenie rozstrzygania spraw o wykroczenia sądom karnym najniższego szczebla.

Współczesny polski model orzecznictwa w sprawach o wykroczenia funkcjonuje na podobieństwo rozwiązań francuskich, lecz w zakresie materialnego prawa nie nawiązuje do francuskiej koncepcji traktowania wykroczenia jako najniższej postaci przestępstwa. Typowe na tle europejskim formalne oddzielenie wykroczeń od przestępstw przesądza o mieszanym charakterze polskiego systemu prawa wykroczeń. Pod tym względem relacji wykroczenie - przestępstwo nawiązuje on do wywodzących się z krajów niemieckich koncepcji administracyjnych, podczas gdy model postępowania w sprawach o wykroczenia odpowiada wzorcom francuskim.

\section{Abstract \\ Evolution of the Polish misdemeanour law system in the XX century}

When the Polish state regained its independence in November 1918, there were three different legal regulation on its territory which represented three types of law for minor offences that were dominant in Europe at that time: French, Austrian and German. The work of creating a uniform system of minor offences law in midwar Poland, included some solutions similar to those of the German model. The codification of criminal administrative procedures of 1928, placed minor offences under the jurisdiction of state administration, however, it provided for court control over it. Codification of the Polish Minor Offences Law, which provided for typically repressive punishments of custody and a fine, was completed and issued in 1932.

In 1951, the Communist regime that ruled Poland after World War II, introduced a completely new, compared with European standards, model of Minor Offences Law. Here, minor offences cases were delegated to a collective body with the participation of a social factor. Although the collective bodies' proceedings were created on the basis of court proceedings, an appeal to the jury of a superior court was introduced 
as in the Austrian administrative model. Custody was replaced by a socialistic penitentiary work, which existed until 1958.

In 1958, collective bodies were given the right to administer custody for more serious offences, which resulted in the restoration of court control over criminal administrative proceedings. The next step, showing a tendency to abandon the Austrian model, was the bill on passing some minor offences to criminal administrative proceedings which was passed in 1966. This bill initiated a division of criminal deeds into crimes and offences based on the monetary value of harm occasioned. A complex codification of the minor offences law, which took place in 1971, continued the process of expanding minor offences law with institutions of criminal law and criminal proceedings. However, in terms of structural composition, Polish minor offences law was typical of an administrative model.

The fall of the Communist regime made it possible to introduce wide changes which fully adjusted minor offences jurisdiction to international standards. The reform of 1990 conferred a form of quasi-public courts, operating at criminal courts of the lowest level, on collective bodies. One of the consequences of connecting collective bodies with the system of common courts was the complete submission of minor offences legislation to court control. In 2001, all collective bodies were disbanded and, thereafter, minor offence cases were to be dealt with by criminal courts of the lowest level.

The modern model of Polish jurisdiction on minor offences is similar to French solutions, however, material law does not refer to the French concept of treating minor offence as the lowest form of crime. The formal separation of crimes and minor offences, which is not typical of European solutions, stems from the mixed character of the Polish minor offences law wherein, crime refers to concepts originating from German countries, whereas the model of minor offences proceedings refers to French models.

Słowa kluczowe: prawo wykroczeń, Polska, orzecznictwo karno-administracyjne Key words: misdemeanour law, Poland, adjudicating on petty offences

Proces kształtowania się polskiego prawa wykroczeń w XX stuleciu przebiegał pod znakiem ścierania się różnorodnych koncepcji teoretycznych, lecz największy wpływ na jego rozwiązania ustawowe i praktykę funkcjonowania wywierały zawsze czynniki polityczne. Problem stworzenia jednolitego systemu prawa wykroczeń stanął przed odrodzonym w listopadzie 1918 r. państwem polskim, gdyż obowiązujące na jego terenie regulacje byłych państw zaborczych reprezentowały trzy dominujące w ówczesnej Europie systemy prawa wykroczeń: francuski, austriacki i niemiecki. Przejęty po zaborcy rosyjskim model francuski miał charakter sądowy, gdyż zgodnie z koncepcją trójpodziału przestępstw 
na zbrodnie, występki i wykroczenia traktował te ostanie jako najniższą postać przestępstwa. Rozstrzyganie spraw o wykroczenia należało do właściwości sądów powszechnych najniższego szczebla, które wprawdzie stosowały uproszczony tryb postępowania, lecz z zachowaniem zasad kontradyktoryjności i jawności rozprawy ${ }^{1}$. Na odmiennych założeniach opierał się dominujący w krajach Europy Środkowo-Wschodniej model austriacki, gdyż zakładał podział wykroczeń na dwie grupy w zależności od ciężaru gatunkowego czynu. Stosunkowo nieliczne poważniejsze wykroczenia o charakterze kryminalnym były uregulowane w kodeksie karnym i jako przestępstwa podlegały właściwości sądów. Z kolei obszerna kategoria wykroczeń zakłócających prawidłowe funkcjonowanie administracji państwowej była traktowana jako naruszenia administracyjno-porządkowe. Wymierzanie kar za tzw. wykroczenia porządkowe leżało w wyłącznej gestii organów administracji i było postrzegane jako stosowanie środków przymusu administracyjnego ${ }^{2}$. Postępowanie w sprawach o wykroczenia przybierało charakter typowo administracyjny, wskutek czego orzeczenia organów administracji mogły być kwestionowane wyłącznie w administracyjnym toku instancji. Ponieważ model austriacki nie traktował orzecznictwa w sprawach o wykroczenia porządkowe jako jednej z form wymiaru sprawiedliwości, stąd orzeczenia karne organów administracji nie były poddane kontroli sądów powszechnych. Przewidziano jedynie możliwość skarżenia prawomocnych orzeczeń o ukaraniu do Trybunału Administracyjnego, który sprawował w trybie kasacyjnym kontrolę legalności decyzji wydanych przez organy administracji ${ }^{3}$.

Kompromisowy charakter w stosunku do dwóch pozostałych systemów posiadał model niemiecki, gdyż traktował wykroczenia jako czyny stanowiące najniższą kategorię przestępstw. Wymierzanie kar za wykroczenia stanowiło wymiar sprawiedliwości, który w zastępstwie sądów karnych sprawowały organy administracji. U podstaw powierzenia administracji orzecznictwa w sprawach o wykroczenia legła obawa przed przeciążeniem sądów sprawami o drobne czyny karalne, wykazujące ścisły związek z zadaniami wykonywanymi przez administrację. Kompetencja organów administracji w zakresie wymierzania kar za wykroczenia miała charakter warunkowy, gdyż była uzależniona od zgody obwinionego. Na każdym etapie postępowania karno-administracyjnego obwinionemu przysługiwało prawo do zgłoszenia sprzeciwu, który skutkował przekazaniem sprawy na drogę sądową. Sąd rozpoznawał sprawę od początku, co w przypadku wniesienia sprzeciwu od nieprawomocnego orzeczenia organu administracji o ukaraniu oznaczało jego uchylenie ${ }^{4}$.

1 J. Skupiński, Model polskiego prawa o wykroczeniach, Wrocław - Warszawa - Kraków - Gdańsk 1974, s. 53-54.

2 W. F. Dąbrowski, Orzecznictwo karno-administracyjne w PRL, Poznań 1967, s. 16-17.

3 J. Jendrośka, Uwagi o istocie orzecznictwa karno-administracyjnego, „Państwo i Prawo” (dalej: PiP) 1958, z. 2, s. 274.

4 Z. Świda, Zarys polskiego prawa o wykroczeniach, Wrocław 1995, s. 13-14. 


\section{Prawo wykroczeń II Rzeczypospolitej}

Kształt polskiego prawa wykroczeń okresu międzywojennego determinował art. 72 konstytucji marcowej, wprowadzający zasadę rozpatrywania spraw o wykroczenia przez sądy powszechne ${ }^{5}$. Nawiązując do modelu niemieckiego konstytucja przewidziała możliwość przekazania $\mathrm{w}$ trybie ustawowym orzecznictwa w sprawach o wykroczenia organom administracji, które miały sprawować je „W zastępstwie sądów”. Subsydiarny charakter orzecznictwa organów administracji podkreślało przyznanie stronom postępowania karno-administracyjnego prawa wniesienia do właściwego sądu odwołania od orzeczeń karnych organów administracji zapadłych w pierwszej instancji. Wyrażoną w konstytucji koncepcję wprowadziło w życie rozporządzenie Prezydenta RP z 22 marca 1928 r. o postępowaniu karno-administracyjnym ${ }^{6}$. Rozporządzenie nie tylko dokonało unifikacji formalnego prawa wykroczeń, lecz przede wszystkim sformułowało ostateczną koncepcję orzecznictwa w sprawach o wykroczenia w Polsce międzywojennej. Postępowanie karno-administracyjne było traktowano jako szczególna postać postępowania administracyjnego, gdyż nie zostało skodyfikowane jednocześnie $\mathrm{z}$ materialnym prawem wykroczeń, lecz w tym samym roku co administracyjne postępowanie ogólne oraz postępowanie przymusowe $w$ administracji ${ }^{7}$. Do orzekania w sprawach o wykroczenia zostały upoważnione terenowe organy administracji ogólnej, chociaż w praktyce pełniących tę funkcję starostów zastępowali referencji karno-administracyjni. Z uwagi na fakt wykonywania orzecznictwa w zastępstwie sądów orzecznictwo organów administracji miały charakter warunkowy, gdyż po wydaniu orzeczenia w I instancji stronom postępowania przysługiwało prawo żądania przekazania sprawy na drogę postępowania sądowego. Skorzystanie z tego uprawnienia skutkowało ponownym rozpoznaniem sprawy przez sąd okręgowy w uproszczonym trybie postępowania karnego, regulowanym przez wydany niemal jednocześnie kodeks postępowania karnego ${ }^{8}$. Ukształtowany w II RP model rozstrzygania spraw o wykroczenia był zatem bliski mieszanemu modelowi pruskiemu, aczkolwiek żądanie drogi sądowej przysługiwało w Polsce dopiero po wydaniu orzeczenia przez organ administracji.

Zakres przedmiotowy orzecznictwa karno-administracyjnego określało kryterium wysokości kar orzekanych za wykroczenia przez organy administracji, którymi były grzywna w wysokości do 3000 złotych oraz areszt w wymiarze

5 M. Zimmermann, Art. 72 Konstytucji a dotychczasowe ustawodawstwo polskie, Lwów 1930, s. 19.

6 Dz. U. nr 38, poz. 365.

7 J. Jendrośka, Rozwój orzecznictwa w sprawach o wykroczenia w Polsce, „Acta Universitatis Wratislaviensis. Przegląd Prawa i Administracji” 1978, t. X, s. 79.

8 M. Zimmermann, Zagadnienia kodyfikacji prawa i postępowania karno-administracyjnego. Notatka z 1962 r., Archiwum Akt Nowych, Zespół akt Ministerstwo Sprawiedliwości, sygn. teczki 2010, s. 100 . 
do 3 miesięcy. Jednolity system polskiego prawa wykroczeń uzupełniała wydana w 1932 r. kodyfikacja materialnego prawa wykroczeń ${ }^{9}$, która traktowana była jako część kompleksowej kodyfikacji prawa karnego II Rzeczypospolitej. Prawo o wykroczeniach nie miało charakteru samodzielnej kodyfikacji, gdyż regulując wybrane zasady odpowiedzialności za wykroczenia w pozostałym zakresie odsyłało do części ogólnej kodeksu karnego. Kodeks karny z 1932 r. formalnie odrzucił francuską koncepcję trójpodziału przestępstw na rzecz podziału dychotomicznego na zbrodnie i występki, zaś wykroczenia jako przestępstwa "mało ważne" i podlegające warunkowo orzecznictwu organów administracji państwowej uregulowano poza kodeksem karnym ${ }^{10}$.

Skodyfikowanie wykroczeń odrębnie od zbrodni i występków uzasadniano względami natury techniczno-legislacyjnej, a także potrzebą odciążenia sądów od rozpatrywania spraw o małym ciężarze gatunkowym. W prawie polskim na przełomie lat dwudziestych i trzydziestych XX stulecia ostatecznie wykształcił się pogląd o formalnej odrębności wykroczenia od przestępstwa, przy jednoczesnym traktowaniu prawa wykroczeń jako części składowej prawa karnego. Ograniczenie katalogu kar do aresztu zasadniczego i grzywny, podlegającej w razie jej nieuiszczenia zamianie na karę aresztu zastępczego, nadawało prawu wykroczeń II RP typowo represyjne oblicze. Również praktyka funkcjonowania orzecznictwa karno-administracyjnego okresu międzywojennym ukierunkowana była na osiągnięcie celów ogólnoprewencyjnych ${ }^{11}$.

\section{Ogólne założenia modelu orzecznictwa karno-administracyjnego Polski Ludowej}

Ukształtowany w II Rzeczypospolitej system prawa wykroczeń obowiązywał do końca 1951 r. gdyż rządzący Polską po II wojnie światowej z namaszczenia Stalina komuniści dla zachowania pozorów legalności swojej władzy przejściowo utrzymali przedwojenny stan prawny. Postępujący wraz z utrwaleniem się władzy polskich komunistów proces przejmowania ,jedynie słusznych” rozwiązań radzieckich objął także system prawa wykroczeń. Przeprowadzona w grudniu 1951 r. gruntowna reforma tego systemu zmieniła w sposób zasadniczy koncepcję orzecznictwa w sprawach o wykroczenia, nawiązując do stworzonej przez naukę radziecką teorii kolegialnego oddziaływania aparatu administracji na obywateli. W myśl tej teorii orzecznictwo karno-administracyjne (orzecznictwo k-a) stanowiło system środków oddziaływania administracyjnego o charakterze społeczno-wychowawczym, wykonywany przy udziale czynnika społecznego. Orzecznictwo to pełniło służebną rolę wobec administracji państwowej przez

9 Rozporządzenie Prezydenta RP z dnia 11 lipca 1932 r. prawo o wykroczeniach (Dz. U. nr 60, poz. 572).

10 M. Bojarski, M. Radecki, Kodeks wykroczeń. Komentarz, Warszawa 2005, s. 7-9.

11 A. Marek, Polskie prawo wykroczeń, Warszawa 1987, s. 21. 
wymierzanie kar względem tych, którzy naruszają przepisy wydane w celu utrzymania spokoju i porządku publicznego. W okresie stalinowskim wykroczenie postrzegano nie tylko w kategoriach czynu godzącego w określone przepisami sfery działalności administracyjnej państwa, lecz także jako akt nieposłuszeństwa czy nawet szkodnictwa wobec zadań realizowanych przez państwo socjalistycz$n \mathrm{e}^{12}$. Ścisłe powiązanie orzecznictwa $\mathrm{w}$ sprawach o wykroczenia $\mathrm{z}$ aktualnymi zadaniami aparatu administracji państwowej znalazło swój wyraz w zastąpieniu terminu prawo wykroczeń określeniem prawo karno-administracyjne ${ }^{13}$.

Przeprowadzona na mocy ustawy z dnia 15 grudnia 1951 r. o orzecznictwie karno-administracyjnym ${ }^{14}$ (u.k.a.) socjalistyczna reforma stworzyła zupełnie nowy na tle standardów europejskich model orzecznictwa w sprawach o wykroczenia. Ich rozpatrywanie powierzono specjalnie $\mathrm{w}$ tym celu powołanym kolegiom $^{15}$, które zostały usytuowane przy terenowych organach administracji państwowej - prezydiach rad narodowych - wszystkich szczebli podziału terytorialnego kraju. Kluczową rolę w nowym systemie orzecznictwa karno-administracyjnego pełniły kolegia przy prezydiach powiatowych, dzielnicowych oraz rad narodowych większych miast, gdyż jako organy I instancji posiadały pełnię uprawnień w zakresie orzekania kar przewidzianych przez u.k.a. Kolegia szczebla wojewódzkiego zostały utworzone w związku z likwidacją sądowej kontroli orzecznictwa karno-administracyjnego i wprowadzeniem wzorowanej na procedurze administracyjnej instytucji odwołania do kolegium II instancji ${ }^{16}$.

Reprezentujący czynnik społeczny członkowie kolegiów orzekających byli wybierani przez terenowe organy władzy państwowej - rady narodowe - spośród kandydatów zgłaszanych przez organizacje społeczne i polityczne ludu pracującego oraz zakłady pracy. Listy kandydatów na członków kolegiów sporządzały prezydia rad narodowych, dzięki czemu organy administracji państwowej w pełni kontrolowały proces obsady personalnej kolegiów orzekających. W myśl zasady kolegialności sprawy o wykroczenia rozpoznawały oparte na czynniku społecznym trzyosobowe składy orzekające, podczas gdy kierujący pracą kolegium przewodniczący $\mathrm{z}$ racji zasiadania $\mathrm{w}$ prezydium rady narodowej miał reprezentować czynnik urzędniczy ${ }^{17}$.

12 M. Zimmermann, Orzecznictwo karno-administracyjne, „Zagadnienia Karno-Administracyjne” (dalej: ZKA) 1965, nr 4, s. 7-8.

13 T. Grzegorczyk, A. Gubiński, Prawo wykroczeń, Warszawa 1995, s. 19.

14 Dz. U. nr 66, poz. 154

15 Kolegia nie miały początkowo specjalnej nazwy, gdyż dopiero w 1958 r. ustawodawca wprowadził określenie kolegia karno-administracyjne. Do tego czasu w języku potocznym określane były mianem kolegiów orzekających. Kompleksowa kodyfikacja polskiego sytemu prawa wykroczeń z maja $1971 \mathrm{r}$. wprowadziła funkcjonujące do końca istnienia kolegialnego modelu rozstrzygania spraw o wykroczenia /2001 r./ określenie kolegia do spraw wykroczeń.

16 K. Siarkiewicz, Kształtowanie się ustroju kolegiów, „Zagadnienia Wykroczeń” (dalej: ZW) 1977, nr 4-5, s. 36

17 M. Łysko, Kształtowanie się ustroju kolegiów orzekających w Polsce Ludowej (1952-1956), „Czasopismo Prawo-Historyczne" (dalej: CPH) 2012, t. LXIV, z. 2, s. 256-257. 
Kolegia orzekające nie wchodziły w skład struktury terenowych organów administracji państwowej, chociaż były usytuowane przy tych organach i przez to zależne od nich pod względem personalno-organizacyjnym. Prezydia rad narodowych nie tylko wykonywały obsługę organizacyjno-prawną działających przy nich kolegiów, lecz także sprawowały bezpośredni nadzór nad ich działalnością. Szczególne uprawnienia nadzorcze przyznano wojewódzkim radom narodowym, które mogły uchylać prawomocne orzeczenia kolegiów „pozbawione podstawy prawnej lub oczywiście niesłuszne”. Ponadto, prezydia te posiadały prawo "udzielania wytycznych dla orzecznictwa oraz kontroli ich wykonania", przy czym wydanie orzeczenia wydane wbrew treści wytycznych stanowiło podstawę do jego uchylenia ${ }^{18}$. W skali całego kraju zwierzchni nadzór nad orzecznictwem karno-administracyjnym sprawował początkowo Prezes Rady Ministrów, który pod koniec grudnia 1954 r. przekazał kompetencje w tym zakres reaktywowanemu urzędowi Ministra Spraw Wewnętrznych (MSW). Wydawane przez ministra wytyczne dla polityki karnej w sprawach o wykroczenia normowały tzw. zasady karania, czyli zasady wymierzania kar za określone rodzaje wykroczeń. Wprawdzie posiadały charakter ogólny i nie mogły wskazywać sposobu rozstrzygnięcia konkretnej sprawy, lecz w praktyce orzecznictwa przyznawano im pierwszeństwo przed regulacjami ustawowymi regulującymi zasady wymiaru kar za wykroczenia ${ }^{19}$.

Stworzeniu pozorów niezawisłości członków składów orzekających służyło oparcie postępowania przed kolegiami na zaczerpniętych z procedury sądowej zasadach kontradyktoryjności oraz skargowości. W praktyce korzyści płynące $\mathrm{z}$ wprowadzenia takich rozwiązań, jak rozstrzyganie spraw o wykroczenia na rozprawie, która odbywała się jawnie ustnie, czy przyznania obwinionemu prawa do obrony przesłaniał fakt zniesienia przysługującego dotychczas osobie ukaranej prawa żądania skierowania sprawy na drogę postępowania sądowego. Zastąpienie kontroli sądowej kontrolą instancyjną kolegiów wyższego szczebla stanowiło nawiązanie do wywodzącej się z Austrii administracyjnej koncepcji prawa wykroczeń ${ }^{20}$, która została połączona $z$ socjalistyczną ideą oddziaływania wychowawczego na sprawców wykroczeń.

Wobec braku kontroli sądowej katalog kar zasadniczych u.k.a. nie przewidywał kary aresztu, która została zastąpiona przez wywodzącą się z ZSRR karę pracy poprawczej. Stosowanie tej kary w miejsce występującej $\mathrm{w}$ sankcjach

18 M. Łysko, Socjalistyczna reforma orzecznictwa karno-administracyjnego Polski Ludowej, [w:] Księga pamiątkowa dla uczczenia pamięci Profesor Krystyny Kamińskiej, red. A. Gaca, Toruń 2013, s. 327-328 .

19 M. Łysko, Kształtowanie polityki karnej w sprawach o wykroczenia przez aparat administracji Polski Ludowej, [w:] Dzieje biurokracji, red. T. Bykowa, A. Górak, J. Legieć, t. VIII, Lublin 2018, s. 171$-173$.

20 M. Siewierski, Ewolucja postępowania w sprawach o wykroczenia, ZW 1978, nr 1, s. 20-21. 
przepisów materialnego prawa wykroczeń kary aresztu miało na celu wdrożenie sprawcy wykroczenia do przestrzegania zasad współżycia społecznego przy współudziale kolektywu załogi zakładu pracy. Istota kary pracy poprawczej polegała na wykonywaniu pracy w uspołecznionym zakładzie pracy z potrąceniem $20 \%$ wynagrodzenia oraz innymi ograniczeniami, przy jednoczesnym podaniu faktu ukarania do wiadomości współtowarzyszy pracy. Osoby niezatrudnione w sektorze państwowym były kierowane do uspołecznionych zakładów pracy w celu odbycia kary, przy czym orzeczenie o ukaraniu karą pracy poprawczej było podawane do publicznej wiadomości w ich miejscu zamieszkania ${ }^{21}$. Drugą $\mathrm{z}$ przewidzianych $\mathrm{w}$ u.k.a. kar zasadniczych była grzywna, która w przypadku nieuiszczenie w terminie przez ukaranego podlegała zamianie na zastępczą karę pracy poprawczej. Kolejnym nowym rozwiązaniem zmierzającym do zmniejszenia represyjności orzecznictwa kolegiów była wprowadzona przez u.k.a. instytucja upomnienia. Stosowane w przypadku stwierdzenia małej szkodliwości społecznej czynu upomnienie przybierało postać potępienia moralnego sprawcy wykroczenia ${ }^{22}$.

Oparta na założeniach demokratyzacji i uspołecznienia orzecznictwa karno-administracyjnego koncepcja wychowawczego oddziaływania na sprawców wykroczeń stanowiła oryginalne rozwiązanie na tle europejskim. Na tle typowo represyjnego systemu prawa wykroczeń Polski międzywojennej socjalistyczny model rozstrzygania spraw o wykroczenia prezentował się korzystnie, lecz praktyka jego funkcjonowania nie potwierdziła jego walorów. Znaczenie nowatorskich rozwiązań wprowadzonych przez u.k.a osłabiał fakt podporządkowania kolegiów terenowym organom administracji państwowej oraz na szczeblu centralnym MSW. Przyznanie ministrowi prawa kształtowania polityki karnej w sprawach o wykroczenia przez wydawanie wiążących kolegia wytycznych czyniło fikcyjną zasadę niezawisłości członków składów orzekających. Z kolei słabość kadrowa pozbawionych wsparcia czynnika fachowego kolegiów skutkowała znaczącym spadkiem poziomu rozstrzygania spraw o wykroczenia w porównaniu $\mathrm{z}$ orzecznictwem wykonywanym jednoosobowo przez referentów karno-administracyjnych ${ }^{23}$. W polskich realiach społeczno-politycznych zupełnie nie sprawdziła się podkreślająca wychowawczy charakter orzecznictwa kara pracy poprawczej, która w przypadku osób zatrudnionych stawała się w praktyce karą grzywny rozłożoną na raty. Wobec sprawców wykroczeń wywodzących się z marginesu społecznego, z reguły uzależnionych od alkoholu, kara pracy poprawczej w ogóle nie była wykonywana. Państwowe zakłady pracy nie chciały bowiem zatrudniać

21 R. Rajkowski, Prawo karno-administracyjne Polski Ludowej, Warszawa 1955, s. 236.

22 Z. Kocel-Krekora, Kierunki rozwoju polskiego prawa wykroczeń, ZW 1987, nr 3, s. 9-10.

23 W. F. Dąbrowski, op. cit., s. 86-87. 
tzw. bumelantów w obawie przed ich demoralizującym wpływem na współtowarzyszy pracy. Zawiodła także kara pracy poprawczej przewidziana na wypadek nieuiszczenia grzywny, której stosowanie wobec sprawców wykroczeń nieposiadających stałego miejsca zatrudnienia prowadziło do ich faktycznej bezkarności ${ }^{24}$.

\section{Reforma prawa karno-administracyjnego Polski Ludowej z 1958 r.}

Położenie przez u.k.a. szczególnego nacisku na wychowanie sprawców wykroczeń w drodze stosowania kar pracy poprawczej i upomnienia, a także organizowanie rozpraw pokazowych, nie przyniosło oczekiwanych rezultatów w postaci spadku liczby wykroczeń. Pozbawione możliwości orzekania kar o charakterze izolacyjnym kolegia nie były w stanie skutecznie przeciwdziałać szerzeniu się społecznej plagi chuligaństwa, u źródeł której tkwiły zaniedbania władz $\mathrm{w}$ sferze pracy społeczno-wychowawczej z młodzieżą oraz nadmierne spożycie alkoholu. Odnotowany w dekadzie lat pięćdziesiątych gwałtowny wzrost liczby wykroczeń o charakterze chuligańskim, popełnianych z reguły przez sprawców znajdujących się w stanie upojenia alkoholowego, zmusił czynniki oficjalne do rezygnacji z wychowawczej dotychczasowej koncepcji orzecznictwa karno-administracyjnego ${ }^{25}$. Podkreślając słuszność założeń leżących u podstaw reformy z grudnia 1951 r., przyznano, iż została ona przeprowadzona na zbyt wczesnym etapie rozwoju społeczeństwa socjalistycznego. Zdaniem władz przemiany w świadomości społecznej przebiegały zbyt wolno w stosunku do reform politycznych i ekonomicznych, które doprowadziły do zbudowania w Polsce ustroju socjalistycznego. W dekadzie lat pięćdziesiątych nadal miały występować grupy społeczne nierespektujące socjalistycznego porządku prawnego, które „można skłonić do przestrzegania prawa jedynie przez zagrożenie ich naruszenia sankcją o znacznym stopniu dolegliwości”26. Przyjęte przez ekipę Władysława Gomułki założenie surowego traktowania notorycznie naruszających socjalistyczny porządek prawny sprawców wykroczeń o charakterze chuligańskim skutkowało zwrotem w kierunku zwiększenia represyjności orzecznictwa kolegiów. Traktowanie orzecznictwa karno-administracyjnego w kategoriach instrumentu zwalczania ujemnych zjawisk społecznych chuligaństwa i alkoholizmu znalazło swój wyraz w przeprowadzonej w 1958 r. korekcie dotychczasowego modelu. Przebiegała ona w dwóch etapach, z których pierwszy stanowiło uchwalenie 22 maja $1958 \mathrm{r}$.

24 M. Łysko, Kara pracy poprawczej w orzecznictwie karno-administracyjnym Polski Ludowej, „Miscellanea Historico-Iuridica" 2008, t. VI, s. 158-159.

25 M. Łysko, Przełom roku 1956 w Polsce a orzecznictwo karno-administracyjne, „Zeszyty Prawnicze UKSW" 2011, nr 11.3, s. 299 -302.

26 J. Jendrośka, Rozwój orzecznictwa..., s. 87. 
tzw. ustawy antychuligańskiej ${ }^{27}$. Celem skutecznego opanowania narastającej wówczas plagi chuligaństwa ustawa upoważniła kolegia do wymierzania kary aresztu zasadniczego za wykroczenia najczęściej przybierające w praktyce postać czynów o charakterze chuligańskim. Wysokość kar grzywny grożących za wskazane $w$ ustawie wykroczenia uległa znacznemu wzrostowi, przy czym nieuiszczona w terminie grzywna podlegała zamianie na karę aresztu zastępczego ${ }^{28}$.

Ustawa antychuligańska była forpocztą szerokich zmian o charakterze systemowym wprowadzonych do u.k.a. w wyniku dokonanej ustawą z 2 grudnia 1958 r. nowelizacjii ${ }^{29}$. Nowelizacja przyjmowała postać reformy pogłębiającej i rozwijającej zapoczątkowany ustawą antychuligańską zwrot w kierunku nadania orzecznictwu karno-administracyjnemu zdecydowanie represyjnego oblicza. Odchodząc od fikcji oddziaływania wychowawczego na sprawców wykroczeń w miejsce kary pracy poprawczej przywrócono typowo represyjną karę aresztu. Kolegia mogły orzekać tę karę wobec sprawców określonych wykroczeń, przy czym katalog tych wykroczeń w kolejnych latach ulegał stopniowemu rozszerzaniu. Znajdowały się $\mathrm{w}$ nim $\mathrm{z}$ reguły wykroczenia przybierające $\mathrm{w}$ praktyce postać czynów o charakterze chuligańskim oraz wykroczenia, do których znamion należała nietrzeźwość sprawcy ${ }^{30}$. Z racji przyznania kolegiom prawa stosowania środka karnego o charakterze izolacyjnym, częściowo przywrócono zniesioną przez reformę z grudnia $1951 \mathrm{r}$. instytucję zadania skierowania sprawy na drogę postępowania sądowego. W nowym ujęciu instytucja ta nie była postrzegana jako wyraz wykonywania przez kolegia orzecznictwa karno-administracyjnego w zastępstwie sądów karnych, gdyż przypisywano jej wyłącznie charakter gwarancyjny ${ }^{31}$. Kontrolą sądowa nie objęto natomiast orzeczeń kolegiów przewidujących zamianę nieuiszczonej $\mathrm{w}$ terminie grzywny na karę aresztu zastępczego. Znowelizowana u.k.a. nie przewidywała żadnych ograniczeń w stosowaniu tej kary, wskutek czego w pierwszych latach po wejściu w życie nowelizacji kolegia bardzo szeroko posługiwały się aresztem zastępczym ${ }^{32}$. Kolejnym przejawem

27 Ustawa z dnia 22 maja 1958 r. o zaostrzeniu odpowiedzialności karnej za chuligaństwo (Dz. U. nr 34, poz. 152.)

28 M. Łysko, Problem chuligaństwa w orzecznictwie karno-administracyjnym w Polsce Ludowej (1952-1989), CPH 2008, t. LX, z. 2, s. 191-193.

29 Ustawa $z$ dnia 2 grudnia 1958 r. o zmianie ustawy z dnia 15 grudnia 1951 r. o orzecznictwie karno-administracyjnym (Dz. U. nr 77, poz. 396).

30 J. Szumski, Chuligański Charakter wykroczenia, [w:] Rozwój polskiego prawa wykroczeń, red. T. Bojarski, M. Mozgawa, J. Szumski, Lublin 1996, s. 82-83.

31 A. Gubiński, Ewolucja stosowanych przez kolegia środków karnych i zasad wymiaru kary, ZW 1977, nr 6, s. 29-30.

32 W pierwszych latach po wejściu w życie nowelizacji u.k.a z grudnia 1958 r. stosowanie kary grzywny z zamianą na areszt zastępczy było bardzo szerokie, gdyż dotyczyło ok. 50-70 \% orzeczonych grzywien. O sytuacji $w$ orzecznictwie karno-administracyjnym, „Poradnik dla Kolegiów Orzekających” (dalej: PdKO) 1960, nr 2, s. 10. Celem ograniczenia skali tego zjawiska wydawane w pierwszej połowie lat sześćdziesiątych wytyczne MSW nakazywały kolegiom ograniczenie stosowania zastępczej kary aresztu do przypadków, gdy ukarany nie miał stałego miejsca zamieszkania lub stałego zatrudnienia. A. Gubiński, Areszt zasadniczy i zastępczy, ZKA 1963, nr 6, s. 61. 
zaostrzenia represyjności „represyjności” systemu prawa karno-administracyjnego będzie podwyższenie o połowę górnej granicy kary grzywny, co doprowadziło do znacznego wzrostu dolegliwości materialnej kar orzekanych przez kolegia za najpoważniejsze wykroczenia. Kolegia pozbawiono możliwości umorzenia postępowania w przypadku stwierdzenia znikomej szkodliwości społecznej czynu, co oznaczało obowiązek każdorazowego ukarania sprawców nawet najdrobniejszych wykroczeń. Jedynym reliktem wychowawczego charakteru orzecznictwa kkarno-administracyjnego pozostała wprowadzona $\mathrm{w}$ miejsce upomnienia kara nagany, aczkolwiek nie mogła być ona orzekana wobec sprawców wykroczeń zagrożonych aresztem zasadniczym ${ }^{33}$.

Korzystnie prezentowały się zmiany dokonane w wyniku reformy $\mathrm{z}$ grudnia 1958 r. w zakresie ustroju i organizacji kolegiów, zwłaszcza odejście od zasady obligatoryjnego tworzenia kolegiów na szczeblu niższym niż powiat. Podstawowym ogniwem w strukturze organizacyjnej uczyniono kolegium przy prezydium powiatowej rady narodowej, wprowadzając zarazem wymóg posiadania wykształcenia prawniczego przez przewodniczącego tego kolegium oraz jego zastępców. Podniesieniu poziomu funkcjonowania kolegiów służyło także wprowadzeniu instytucji przewodniczących składów orzekających, którzy „w miarę możliwości” powinni byli rekrutować się spośród osób posiadających fachowe kwalifikacje ${ }^{34}$.

\section{Ustawa o przekazaniu}

Dokonana w duchu „represyjnym” nowelizacja u.k.a oznaczała niemal całkowite odejście od socjalistycznej zasady oddziaływania wychowawczego na sprawców wykroczeń. Z punktu widzenia władz reforma z grudnia 1958 r. była niewątpliwie sukcesem, gdyż przyznanie kolegiom możliwości stosowania surowych kar przyczyniło się do ograniczenia społecznej plagi chuligaństwa oraz ogólnej poprawy stanu bezpieczeństwa w kraju. Z kolei zmiany o charakterze organizacyjno-ustrojowym przyniosły efekt w postaci odczuwalnej poprawy poziomu funkcjonowania orzecznictwa karno-administracyjnego, w tym rozwiązania problemu nadmiernego wpływu do wniosków o ukaranie sporządzanych przez organy ścigania. Jednakże zbyt formalistyczny charakter przepisów znowelizowanej u.k.a., nakładających obowiązek ukarania każdego sprawcy wykroczenia, zmuszał kolegia do prowadzenia postępowania nawet w sprawach o niewielkim

33 M. Łysko, Reforma prawa karno-administracyjnego Polski Ludowej z 1958 r, „Z Dziejów Prawa” 2014, t. 7, s. 238-239.

34 Na przewodniczących składów orzekających w pierwszej kolejności miały być powoływane osoby posiadające wykształcenie prawnicze, znajomość zasad prawa karno-administracyjnego lub przynajmniej znajomość ,jednego z działów administracji państwowej”. M. Łysko, Zasady obsady personalnej kolegiów karno-administracyjnych Polski Ludowej, „Miscellanea Historico-Iuridica” 2013, t. XII, s. 328 
ciężarze gatunkowym. Rozpatrywanie tego rodzaju spraw stanowiło poważne obciążenie dla kolegiów, które zgodnie z wytycznymi MSW miały koncentrować się przede wszystkim na karaniu sprawców społecznie niebezpiecznych wykroczeń alkoholowo-chuligańskich oraz wykroczeń przeciwko bezpieczeństwu ruchu drogowego ${ }^{35}$. Obok coraz bardziej odczuwalnej potrzeby złagodzenia nadmiernej represyjności cechującej system polskiego prawa wykroczeń na początku lat sześćdziesiątych, na jego dalszy rozwój istotny wpływ wywarła przyjęta przez władze gomułkowskie koncepcja tzw. rozwarstwienia przestępczości. Determinująca politykę legislacyjną w dziedzinie szeroko pojmowanego prawa karnego koncepcja zakładała odmienne podejście do drobnych, przypadkowych naruszeń porządku prawnego oraz zamachów wyrządzających istotne szkody interesowi społecznemu ${ }^{36}$.

Realizacja tej koncepcji na gruncie prawa wykroczeń nastąpiła w drodze uchwalenia w czerwcu 1966 r. tzw. ustawy o przekazaniu ${ }^{37}$, która miała realizować dwa zasadnicze cele. Pierwszym $\mathrm{z}$ nich było przekształcenie w wykroczenia dziesięciu czynów o charakterze ogólnokryminalnym, przybierających dotychczas postać drobnych występków przeciwko mieniu. Nadanie im rangi wykroczeń uzasadniano potrzebą odciążenia sądów od rozpatrywania spraw o niewielkim ciężarze gatunkowym, których przekazanie do orzecznictwa karno-administracyjnego wiązało się z przyśpieszeniem i potanieniem postępowania. Operacja przekazania dotychczasowych występków do właściwości kolegiów karno-administracyjnych polegała na wydzielaniu za pomocą wskaźnika kwotowego lżejszych przypadków poszczególnych przestępstw. Ustawa zapoczątkowała trwający do dnia dzisiejszego proces podziału czynów o charakterze ogólnokryminalnym na przestępstwa i wykroczenia w zależności od wartości przedmiotu lub wysokości szkody ${ }^{38}$. Przesunięcie do grupy wykroczeń lżejszych przypadków niektórych przestępstw przeciwko mieniu prowadziło do zacierania się granic pomiędzy przestępstwem a wykroczeniem. Koniecznym następstwem tego zabiegu legislacyjnego było ukształtowanie zasad odpowiedzialności za wykroczenia „przekazane” oparte na regulacjach prawa karnego materialnego oraz zbliżenie zasad postępowania w sprawach o wykroczenia do zasad procesu karnego. Wraz z poddaniem orzecznictwu kolegiów pierwszych dziesięciu występków przeciwko mieniu wśród przedstawicieli doktryny utrwaliło się przekonanie, iż prawo wykroczeń stanowi dziedzinę szeroko pojmowanego prawa karnego. Z kolei postępowanie w sprawach

35 Wytyczne Ministra Spraw Wewnętrznych w zakresie orzecznictwa karno-administracyjnego na rok 1960, PdKO 1960, nr 2, s. 2.

36 S. Walczak, Niektóre problemy kodyfikacji prawa karnego, PiP 1968, nr 4-5, s. 594.

37 Ustawa z dnia 17 czerwca 1966 r. o przekazaniu niektórych drobnych przestępstw jako wykroczeń do orzecznictwa karno-administracyjnego (Dz. U. nr 23, poz. 149)

38 T. Bojarski, Ewolucja polskiego..., s. 17-18. 
o wykroczenia zaczęto traktować jako szczególny rodzaj procedury karnej, a nie postępowania administracyjnego ${ }^{39}$.

Drugim z celów ustawy o przekazaniu było złagodzenie nadmiernej represyjności cechującej system materialnego prawa wykroczeń po reformie z grudnia 1958 r. Dokonano tego w drodze wzbogacenia metod i środków odziaływania na sprawców wykroczeń, zarówno tych powstałych w wyniku depenalizacji dotychczasowych występków, jak też pozostałych podlegających właściwości kolegiów karno-administracyjnych. Ustawa o przekazaniu podkreśliła wyjątkowy charakter kary aresztu zasadniczego, ustanawiając szczegółowe dyrektywy leżące u podstaw orzekania tej kary. Wprowadzono nieznaną dotychczas polskiemu prawu wykroczeń instytucję warunkowego zawieszenia wykonania kary aresztu, przyjmując za jej podstawę pozytywną prognozę dotyczącą sprawcy wykroczenia. Zakres stosowania nadużywanej przez kolegia w pierwszej połowie lat sześćdziesiątych zastępczej kary aresztu uległ ograniczeniu do przypadków, gdy okoliczności sprawy wskazywały na bezskuteczność egzekucji orzeczonej grzywny. Dążąc do ograniczenia nadmiernej represyjności orzecznictwa karno-administracyjnego ustawa o przekazaniu wprowadziła możliwość odstąpienia od wymierzania kary w przypadkach zasługujących, zdaniem kolegium, na szczególne uwzględnienie ${ }^{40}$. Rezygnacja $z$ ukarania sprawcy mogła być połączona z zastosowaniem upomnienia lub innego środka odziaływania społecznego, którego celem było przywrócenie naruszonego porządku prawnego lub wyrównanie wyrządzonej szkody. Nawiązując do socjalistycznej koncepcji oddziaływania wychowawczego na sprawców wykroczeń, ustawa z czerwca 1966 r. przewidziała możliwość odmowy wszczęcia postępowania na rzecz przekazania sprawy kierownictwu zakładu pracy. U podstaw decyzji o rezygnacji z ukarania sprawcy, leżało przekonanie, iż zastosowane w zakładzie pracy środki wystarczą do wdrożenia sprawcy do poszanowania praw i zasad współżycia społecznego ${ }^{41}$. Ustawa o przekazaniu przyczyniła się do podniesieniu poziomu funkcjonowania orzecznictwa karno-administracyjnego kolegiów przez wprowadzenie instytucji radcy do spraw kolegium, który musiał posiadać wyższe wykształcenie prawnicze. Jego zadaniem była obsługa organizacyjnoprawna kolegiów upoważnionych do orzekania w zakresie rozszerzonym o wykroczenia powstałe w wyniku depenalizacji dotychczasowych występków ${ }^{42}$.

39 A. Marek, Problemy reformy polskiego prawa wykroczeń, [w:] Problemy odpowiedzialności karnej. Księga ku czci Profesora Kazimierza Buchały, red. Z. Ćwiąkalski, M. Szewczyk, S. Waltoś, A. Zoll, Kraków 1994, s. 196.

40 M. Łysko, Prace nad kodyfikacją materialnego prawa wykroczeń w Polsce Ludowej (1960-1971), Biakystok 2016, s. 147-150.

41 A. Mirończuk, Oddziaływanie wychowawcze zakładów pracy, ZKA 1966, nr 5, s. 91.

42 M. Siewierski, Ewolucja postępowania w sprawach o wykroczenia, ZW 1978, nr 1, s. 22 


\section{Kodyfikacja prawa wykroczeń Polski Ludowej z 1971 r.}

Kompleksową kodyfikację prawa wykroczeń Polski Ludowej, której trzon stanowił kodeks wykroczeń, kontynuowała zapoczątkowana ustawą o przekazaniu tendencję przesuwania drobnych przestępstw do kategorii wykroczeń kontynuował uchwalony 20 maja $1971 \mathrm{r}$. kodeks wykroczen ${ }^{43}$. Stanowił on trzon kompleksowej kodyfikacji prawa wykroczeń Polski Ludowej, w skład której wchodziły także kodeks postepowania w sprawach o wykroczenia ${ }^{44} \mathrm{i}$ ustawa o ustroju kolegiów do spraw wykroczeń ${ }^{45}$. Efektem prowadzonych w latach 1960-1971 prac kodyfikacyjnych było wzbogacenie polskiego systemu prawa wykroczeń kolejnymi instytucjami o charakterze prawnokarnym, dotyczącymi zwłaszcza zasad odpowiedzialności i karalności sprawców wykroczeń. Kodyfikacja materialnego prawa wykroczeń realizowała przyjętą przez jego twórców koncepcję polaryzacji wykroczeń i zróżnicowania odpowiedzialności sprawców wykroczeń w zależności od ciężaru gatunkowego czynu. Wobec sprawców wykroczeń cechujących się znacznym stopniem społecznego niebezpieczeństwa, zwłaszcza tych powstałych w wyniku tzw. depenalizacji dotychczasowych występków, miały być stosowane środki o charakterze typowo represyjnym, takie jak areszt i grzywna. W przypadku wykroczeń o niewielkim ciężarze gatunkowym, których sprawcy przypadkowo popadli w konflikt z prawem, zakładano szerokie stosowanie środków oddziaływania wychowawczego przez zakłady pracy i organizacje społeczne ${ }^{46}$.

Stosownie do powyższych założeń kodyfikacja z 1971 r. nie tylko porządkowała, lecz jednocześnie wzbogacała system kar i środków karnych stosowanych wobec sprawców wykroczeń. Znaczenie porządkujące miało wyodrębnienie w kodeksie wykroczeń kar zasadniczych i dodatkowych, przy czym katalog tych pierwszych uzupełniła zaczerpnięta z kodeksu karnego kara ograniczenia wolności. Ponadto, do rangi kary zasadniczej została podniesiona kara nagany, dotychczas stosowana wyłącznie w przypadku nadzwyczajnego złagodzenia kary. W katalogu kar dodatkowych nowością była kara zakazu prowadzenia pojazdów mechanicznych, stosowana obligatoryjnie wobec sprawców wykroczenia polegającego na prowadzeniu pojazdu mechanicznego w stanie nietrzeźwości $^{47}$. Leżące u podstaw prac kodyfikacyjnych materialnego prawa wykroczeń założenie wzajemnej synchronizacji części ogólnej tego prawa z kodeksem karnym skutkowało jednolitym unormowaniem zasadniczych dyrektyw wymiaru kary. Wzorem kodeksu karnego przy wymiarze kary za wykroczenie należało

43 Dz. U. nr 12, poz. 114

44 Dz. U. nr 12, poz. 116.

45 Dz. U. nr 12, poz. 117

46 Nowe ustawy o wykroczeniach - narzędziem ochrony porządku publicznego i dyscypliny społecznej, ZKA 1971, nr 3, s. 6.

47 J. Szumski, Środki penalne w polskim prawie wykroczeń na tle doświadczeń praktyki, Lublin 1995, s. $109-111$. 
uwzględniać stopień społecznego niebezpieczeństwa czynu oraz cele ogólnoprewencyjne i szczególnoprewencyjne ${ }^{48}$. Niewielkie różnice występowały także w zakresie okoliczności dotyczących popełnionego czynu i osoby sprawcy, istotną natomiast odmiennością było wymienienie przez kodeks wykroczeń szeregu okoliczności łagodzących i obciążających. W przeciwieństwie do nastawionego na osiągnięcie celów ogólnoprewencyjnych kodeksu karnego, kodyfikacja prawa wykroczeń Polski Ludowej wysuwała na pierwszy plan prewencję szczególną. Kodeks wykroczeń w szerokim zakresie przewidywał możliwość odstąpienia od wymierzania kary i ewentualne stosowanie wobec sprawców korzystających z dobrodziejstwa tej instytucji środków oddziaływania społecznego. Idea prewencji szczególnej legła u podstaw zamieszczenia w kodeksie instytucji środków oddziaływania wychowawczego, która została znacznie rozbudowana na tle rozwiązań ustawy o przekazaniu. Posiadała decydujące znaczenie w przypadku czynów popełnionych w warunkach recydywy wielokrotnej, prowadząc do przyjęcia za podstawową przesłankę nadzwyczajnego zaostrzenia kary winy umyślnej sprawcy wykroczenia ${ }^{49}$.

Zarówno wprowadzenie do kodyfikacji prawa wykroczeń szeregu rozwiązań z dziedziny prawa karnego, jak też oficjalne zastąpienie określenia prawo karno-administracyjne terminem prawo wykroczeń, nie oznaczało całkowitego odejścia od administracyjnego modelu prawa wykroczeń. Zabieg ten miał jedynie na celu podkreślenie autonomicznego charakteru prawa wykroczeń w szeroko pojmowanym obszarze prawa karnego. $\mathrm{Z}$ uwagi na fakt utrzymania istotnych różnic pomiędzy wykroczeniem a przestępstwem, prawo wykroczeń nie stanowiło części składowej prawa karnego sensu stricto ${ }^{50}$.

Według twórców kodeksu wykroczeń różnica między tymi pojęciami sprowadzała się do trzech elementów. Pierwszym z nich był czynnik merytoryczny $\mathrm{w}$ postaci stopnia społecznego niebezpieczeństwa czynu, stąd na tle przestępstw wykroczenie było czynem społecznie niebezpiecznym w stopniu znikomym. Kolejnym kryterium była możliwość orzekania przez kolegia, obok typowych kar o charakterze represyjnym, także pozakarnych środków oddziaływania wychowawczego, ukierunkowanych na wdrożenie sprawcy do przestrzegania zasad współżycia społecznego w państwie socjalistycznym. Jednakże najważniejsza różnica między tymi dwoma rodzajami czynów karalnych polegała na poddaniu wykroczeń orzecznictwu organów o charakterze quasi-sądowym, jakimi pod rządami kodyfikacji z 1971 r. stały się kolegia do spraw wykroczeńn ${ }^{51}$. Zmiana

48 Prawo o wykroczeniach. Projekt, Warszawa 1970, s. 65.

49 B. Adamiak, Ewolucja systemu kar w orzecznictwie w sprawie wykroczeń w PRL, „Acta Universitatis Wratislaviensis. Przegląd Prawa i Administracji” 1976, t. VIII, s. 111-113.

50 A. Marek, Prawo wykroczeń, [w:] System Prawa Karnego, t. 1, Zagadnienia ogólne, Warszawa 2010, s. 39.

51 J. Jakubowska-Hara, Grzywna w prawie wykroczeń, Model ustawowy i praktyka, Warszawa 2004, s. $83-84$. 
nazwy tych organów miała charakter symboliczny, gdyż w dalszym ciągu funkcjonujące przy terenowych organach administracji ${ }^{52}$ kolegia podlegały zwierzchniemu nadzorowi MSW.

O ile ustrój organów orzekających w sprawach o wykroczenia oparty był na modelu administracyjnym, o tyle kodyfikacja formalnego prawa wykroczeń ukształtowała postępowanie przed kolegiami w pełni na podobieństwo procedury karnej. W kodeksie postępowania w sprawach o wykroczenia przyjęto odpowiednio uproszczone zasady procesowe właściwe postępowaniu sądowemu $\mathrm{w}$ sprawach o przestępstwa. Zasady te miały również zastosowanie w postępowaniu przed kolegium drugiej instancji, które rozpatrywały odwołania od orzeczeń o ukaraniu karą grzywny ${ }^{53}$. Orzekana w zdecydowanej większości spraw rozpatrywanych przez kolegia kara grzywny nie została poddana kontroli sądowej, gdyż zajmujący dominującą pozycję w strukturach władzy komunistycznej resort spraw wewnętrznych zdecydowanie sprzeciwiał się rozszerzeniu zakresu tej kontroli. Pod rządami kodyfikacji z 1971 r. żądanie skierowania sprawy na drogę postepowania sądowego przysługiwało jedynie $\mathrm{w}$ razie ukarania zasadniczą karą aresztu lub karą ograniczenia wolności, czyli kar posiadających niewielkie znaczenie w praktyce orzecznictwa kolegiów. Znaczenie kontroli sądowej pomniejszał fakt pozostawienia poza jej zakresem przypadków orzeczenia zastępczej kary aresztu na wypadek nieuiszczenia grzywny, której szerokie możliwości stosowania przewidywał kodeks wykroczeń. Nastawione na osiągnięcie celów ogólnoprewencyjnych wytyczne MSW zachęcały kolegia do korzystania z tych możliwości ${ }^{54}$, zwłaszcza w pozbawionym wszelkich gwarancji praw osoby obwinionej postępowaniu przyśpieszonym. Wprowadzany na podstawie zarządzeń MSW lub wojewodów ten szczególny tryb postępowania przewidywał natychmiastową wykonalność orzeczeń kolegiów zapadłych w pierwszej instancji, w tym orzeczeń o ukaraniu grzywną podlegającą zamianie na areszt zastępczy. Z założenia wyjątkowy tryb postępowania przyśpieszonego był w praktyce nadużywany, zwłaszcza w celu represjonowania opozycji antykomunistycznej i uczestników masowych protestów przeciwko polityce władz ${ }^{55}$.

52 W wyniku przeprowadzonej w latach 1973-1975 reformy struktur administracji terenowej, kolegia zostały usytuowane przy wprowadzonych w miejsce dotychczasowych prezydiów rad narodowych monokratycznych organach administracji terenowej. Kolegia funkcjonowały przy naczelnikach gmin, naczelnikach urzędów miejsko-gminnych i prezydentach miast. T. Bojarski, Polskie prawo wykroczeń. Zarys wykładu, Warszawa 2012, s. 25.

53 T. Bojarski, Ewolucja polskiego..., s. 19.

54 W 1971 r. pozbawionych wolności zostało 21227 osób, a na początku lat osiemdziesiątych $\mathrm{w}$ aresztach osadzono 38003 sprawców wykroczeń. Niemal trzy czwarte $\mathrm{z}$ nich zostało pozbawionych wolności w następstwie zarządzenia wykonania przez kolegium kary aresztu zastępczego. J. Szumski, Środki karne stosowane wobec sprawców wykroczeń, [w:] Problemy recydywy i drobnej przestępczości w prawie Polski i RFN, red. J. Skupiński, Wrocław 1984, s. 186

55 Szerzej na ten temat: Kolegia ds. wykroczeń w PRL (rozwiązania ustawowe i praktyka). Broszura opracowana i wydana staraniem Komisji Interwencji i Praworządności NSZZ „Solidarność” oraz Małopolskiego Komitetu Walki o Praworządność, Warszawa - Kraków 1987, s. 
Do końca okresu komunistycznego resort spraw wewnętrznych na zasadzie swoistego monopolu traktował prawo wykroczeń jako narzędzie służące zapewnieniu porządku i bezpieczeństwa publicznego, a także zwalczaniu opozycji antykomunistycznej ${ }^{56}$. Czynnik administracyjny wywierał decydujący wpływ zarówno na kształt personalny kolegiów, jak też ich politykę orzeczniczą przez wykonywanie nadzoru bezpośredniego i zwierzchniego. Wobec instrumentalnego traktowania orzecznictwa kolegiów przez organy administracji państwowej akcentowane przez twórców kodyfikacji prawa wykroczeń z 1971 r. zasady i gwarancje procesowe miały w praktyce charakter fasadowy ${ }^{57}$. Nie udało się także zrealizować koncepcji oddziaływania wychowawczego wobec sprawców drobnych wykroczeń, gdyż orzecznictwo kolegiów do spraw wykroczeń ewoluowało w kierunku coraz bardziej zaostrzonej i schematycznie stosowanej represji. Sprzyjał temu system kar przyjęty w kodeksie wykroczeń, który pomimo propagandowej deklaracji o wyjątkowym charakterze kary aresztu przewidywał tą najsurowszą karę znacznie częściej niż mającą ją wypierać karę ograniczenia wolności ${ }^{58}$.

Pomimo wprowadzenia do kodyfikacji materialnego i procesowego prawa wykroczeń szeregu rozwiązań prawa karnego i procedury karnej, decydujące znaczenie dla praktyki orzecznictwa kolegiów posiadał fakt utrzymania typowych dla modelu administracyjnego rozwiązań ustrojowych. Wprowadzony w okresie stalinowskim socjalistyczny model orzecznictwa karno-administracyjnego funkcjonował aż do końca systemu komunistycznego w Polsce, gdyż kilkakrotne korekty nie naruszyły jego podstawowych założeń. Ten państwowo-społeczny model orzekania w sprawach o wykroczenia stanowił rozwiązanie pośrednie między systemem sądowym a administracyjnym, z przewagą elementów tego ostatniego. System orzecznictwa karno-administracyjnego Polski Ludowej stanowił w skali europejskiej dosyć oryginalne rozwiązanie i pomimo swoich niedostatków wyróżniał się pozytywnie na tle pozostałych państw socjalistycznych, które co do zasady wzorowały się na administracyjnym modelu austriackim. W państwach tych nie występowały specjalne organy orzekające w sprawach o wykroczenia, przez co orzecznictwo to miało charakter branżowy. Poszczególne organy administracji rozstrzygały sprawy o wykroczenia związane $\mathrm{z}$ zakresem ich podstawowej działalności, a ich rozstrzygnięcia $\mathrm{z}$ reguły nie podlegały kontroli sądowej. Natomiast model polski jedynie początkowo opierał się na wzorcach radzieckich, lecz po przełomie 1956 r.jego rozwój przebiegał własną autonomiczną drogą. Do pozytywów funkcjonującego w Polsce Ludowej w latach 1952-1990 modelu należały kolegialność orzekania i udział w nim

56 J. Szumski, Główne kierunki polityki karnej realizowane przez kolegia do spraw wykroczeń w latach 1972-1989, „Archiwum Kryminologii” 1993, t. XIX, s. 131.

57 T. Grzegorczyk, O systemie organów orzekajacych w sprawach o wykroczenia le lege lata $i$ de lege ferenda, [w:] Rozwój polskiego..., s. 134-135.

58 A. Marek, Problemy reformy..., s. 197. 
czynnika społecznego. W praktyce zalety te schodziły na dalszy plan wobec podporządkowania kolegiów organom administracji państwowej i znikomego zakresu kontroli sądowej ${ }^{59}$.

\section{Reformy systemu prawa wykroczeń w III Rzeczypospolitej}

Dopiero upadek systemu komunistycznego umożliwił przeprowadzenie daleko idących zmian modelowych, które w pełni dopasowały orzecznictwo w sprawach o wykroczenia do standardów międzynarodowych. Przeprowadzona w 1990 r. reforma ${ }^{60}$ zapoczątkowała trzeci etap rozwoju polskiego prawa wykroczeń, gdyż całkowicie uniezależniła kolegia od aparatu administracji państwowej pod względem ustrojowym i organizacyjno-prawnym. Kolegia zyskały charakter quasi-sądów społecznych, które funkcjonowały w strukturach organizacyjnych wymiaru sprawiedliwości przy sądach karnych najniższego szczebla. Prezesi tych sądów wykonywali bezpośredni nadzór nad orzecznictwem kolegiów, a kompetencje w zakresie nadzoru zwierzchniego przysługiwały Ministrowi Sprawiedliwości. Konsekwencją powiązania kolegiów z systemem sądów powszechnych była likwidacja kolegiów drugiej instancji i całkowite poddanie orzecznictwa w sprawach o wykroczenia kontroli sądowej. Wzorem modelu pruskiego osobie ukaranej przez kolegium przysługiwało prawo żądania skierowania sprawy na drogę postępowania sądowego, przy czym żądanie to nie było typowym środkiem odwoławczym. Skutkiem skierowania sprawy o wykroczenie na drogę sadową było jej ponowne rozpatrzenie przez sąd karny najniższego szczebla, który nie był związany ustaleniami kolegium i w związku z tym mógł orzec także na niekorzyść obwinionego ${ }^{61}$. Brak związania sądu zakazem reformationis in peius rekompensowało prawo wniesienia środka odwoławczego od niekorzystnego z punktu widzenia obwinionego wyroku do sądu wyższej instancji. Również na drodze sądowej mogło nastąpić wzruszenie prawomocnego rozstrzygnięcia kolegium, podczas gdy w okresie Polski Ludowej kompetencje $\mathrm{w}$ tym zakresie przysługiwały specjalnym komisjom powoływanym przez organy administracji ogólnej szczebla wojewódzkiego ${ }^{62}$.

Usytuowanie kolegiów przy sądach najniższego szczebla zdecydowanie zbliżyło model polskiego prawa wykroczeń do wzorców francuskich, zakładających

59 T. Bojarski, Ewolucja polskiego systemu prawa wykroczeń na tle rozwiązań europejskich, „Annales UMCS, Sectio G" 1993, vol. XL., s. 26-27.

60 Na mocy ustawy z dnia 8 czerwca 1990 r. o zmianie ustaw: Kodeks postępowania karnego, Kodeks postępowania w sprawach o wykroczenia, o ustroju kolegiów do spraw wykroczeń i Kodeks pracy (Dz. U. nr 43, poz. 251)

61 J. Grajewski, E. Skrętowicz, Kodeks postępowania w sprawach o wykroczenia. Komentarz, Warszawa 1995, s. 312- 314.

62 M. Łysko, Obwiniony jako uczestnik postępowania w sprawach o wykroczenia - wczoraj i dziś, [w:] Role uczestników postępowań sq̨dowych - wczoraj, dziś, jutro, red. D. Gil, E. Kruk, Lublin 2015, s. 252. 
rozstrzyganie spraw o wykroczenia przez organy wymiaru sprawiedliwości ${ }^{63}$. Towarzysząca przemianom polityczno-ustrojowym początków III RP tendencja do „usądowienia” prawa wykroczeń uległa pogłębieniu wraz z wejściem w życie kompleksowej kodyfikacji prawa karnego z 1997 r. $^{64}$ Dokonane rok później zmiany miały na celu dostosowanie materialnego i procesowego prawa wykroczeń do nowych rozwiązań prawa karnego, co znacznie zbliżyło te dwa autonomiczne wobec siebie działy szeroko pojętego prawa karnego. Ukształtowany w duchu represyjnym katalog kar zasadniczych kodeksu wykroczeń uległ znacznemu złagodzeniu wskutek obniżenia górnego pułapu kary aresztu i kary ograniczenia wolności z trzech do jednego miesiąca. Reforma z 1998 r. ${ }^{65}$ nadała wyjątkowy charakter zastępczej karze aresztu, wprowadzając wymóg zamiany nieuiszczonej $\mathrm{w}$ terminie grzywny $\mathrm{w}$ pierwszej kolejności zamianie na pracę społecznie użyteczną. Zastępując termin kary dodatkowe bardziej adekwatnym określeniem środki, do kompetencji sądów przekazano orzekanie zakazu prowadzenia pojazdów mechanicznych wobec sprawców znajdujących się w stanie nietrzeźwości oraz przepadku przedmiotów pochodzących z wykroczenia lub służących do jego popełnienia ${ }^{66}$. Zmianie uległ także charakter prawny instytucji żądania skierowania sprawy na drogę postępowania sądowego. Instytucja ta zyskała rangę zwykłego środka odwoławczego, podczas gdy dotychczas była szczególną formą kontroli sądowej orzeczeń w sprawach o wykroczenia ${ }^{67}$.

Wejście w życie ustawy z dnia 2 kwietnia 1997 r. Konstytucja Rzeczypospolitej Polskiej ${ }^{68}$ przesądziło o likwidacji kolegiów do spraw wykroczeń, gdyż ustawa zasadnicza powierzała sprawowanie wymiaru sprawiedliwości wyłącznie sądom i trybunałom. Na mocy przepisów przejściowych Konstytucja przewidziała wykonywanie wymiaru sprawiedliwości przez kolegia przy sądach rejonowych w czteroletnim okresie przejściowym, aczkolwiek z wyłączeniem możliwości orzekania kary aresztu ${ }^{69}$. Definitywne zakończenie działalności tych quasi-sądowych organów orzekających nastąpiło wraz z przekazaniem 16 października $2001 \mathrm{r}$. rozstrzygania spraw o wykroczenia do kompetencji sądów rejonowych. Uchwalony na potrzeby tej reformy nowy kodeks postę-

63 T. Bojarski, Ewolucja polskiego..., s. $22-23$.

64 Ustawa z dnia 6 czerwca 1997 r. - Kodeks karny (Dz. U. nr 88, poz. 553).

65 Przeprowadzona ustawą z dnia 28 sierpnia 1998 r. o zmianie ustawy - Kodeks wykroczeń, ustawy Kodeks postępowania w sprawach o wykroczenia, ustawy o ustroju kolegiów do spraw wykroczeń, ustawy - Kodeks pracy oraz niektórych innych ustaw (Dz. U. nr 113, poz. 717).

66 M. Łysko, Prace nad kodyfikacja..., s. 322.

67 T. Bojarski, Zmiany dostosowawcze przepisów prawa wykroczeń do nowych kodeksów karnych, [w:] Rozważania o prawie karnym. Księga pamiątkowa z okazji siedemdziesięciolecia urodzin Profesora Aleksandra Ratajczaka, red. A. Szwarc, Poznań 1999, s. 33 -34.

68 Dz. U. nr 78, poz. 483.

69 G. Kasicki, A. Wiśniewski, Kodeks wykroczeń. Kodeks postępowania w sprawach o wykroczenia. Komentarz do noweli z sierpnia 1998 r., Warszawa 1999, s. 3. 
powania w sprawach o wykroczenia ${ }^{70}$ (k.p.s.w.) dokonał całkowitego „usądowienia" postępowania, które obecnie stanowi uproszczoną wersję procedury karnej.

\section{Zakończenie}

Wobec przekazania w 2001 r. spraw o wykroczenia do kompetencji sądów karnych współczesny polski model orzecznictwa w sprawach o wykroczenia został ukształtowany na wzór francuski. Natomiast w zakresie materialnego prawa polskie rozwiązania odbiegają od francuskiej koncepcji traktowania wykroczenia jako najniższej postaci przestępstwa. Zapoczątkowane w okresie międzywojennym formalne wyłączenie wykroczeń z ogólnego pojęcia „przestępstwa” cały czas towarzyszyło procesowi ewolucji polskiego prawa wykroczeń, które uległo przekształceniu w autonomiczną dziedzinę szeroko pojmowanego prawa karnego. Typowe na tle europejskim formalne oddzielenie wykroczeń od przestępstw przesądza o mieszanym charakterze polskiego systemu prawa wykroczeń. Pod tym względem relacji wykroczenie-przestępstwo nawiązuje on do administracyjnych koncepcji ukształtowanych w krajach niemieckich, podczas gdy w pełni „usądowiony" model postępowania w sprawach o wykroczenia odpowiada wzorcom francuskim.

Obowiązująca od 2001 r. koncepcja całkowitego „usądowienienia” orzecznictwa w sprawach o wykroczenia nie do końca sprawdziła się w praktyce. Po likwidacji kolegiów do spraw wykroczeń sądy karne nie zostały dostatecznie wzmocnione pod względem kadrowym, wskutek czego do dzisiaj nie są w stanie poradzić sobie $\mathrm{z}$ terminowym rozpatrywaniem masowo napływających spraw o wykroczenia. Nawet utworzenie specjalnych wydziałów grodzkich zajmujących się wykroczeniami nie przyniosło oczekiwanych rezultatów. Świadczy o tym wycofanie się z tego pomysłu na rzecz powierzenia z początkiem $2010 \mathrm{r}$. orzecznictwa w sprawach o wykroczenia wydziałom karnym sądów rejonowych. Zajmujący się dotychczas rozpatrywaniem spraw o przestępstwa sędziowie zostali dodatkowo obciążeni obowiązkiem rozpoznawania szeregu spraw o wykroczenia, $\mathrm{z}$ reguły kierowanych na drogę sądową wskutek odmowy przyjęcia przez obwinionego mandatu karnego. Niewielki ciężar gatunkowy spraw o wykroczenia w połączniu $z$ ich nieskomplikowanym stanem faktycznym prowadzi do wykształcenia się wśród sędziów praktyki „mechanicznego" rozstrzygania tej kategorii spraw, jako mało istotnych na tle społecznie niebezpiecznych przestępstw. Marginalizacji orzecznictwa w sprawach o wykroczenia niewątpliwie sprzyja przeprowadzona w $2003 \mathrm{r}$. reforma kodeksu postępowania w sprawach o wykroczenia $^{71}$, u podstaw której legło założenie uproszczenia pracy sądów. Ponieważ

$70 \quad$ Ustawa z dnia 24 sierpnia 2001 r. (Dz. U. nr 106, poz. 1148).

71 Ustawa z dnia 22 maja 2003 r. o zmianie ustawy - Kodeks postępowania w sprawach o wykroczenia (Dz. U. nr 109, poz. 1031). 
wydziały grodzkie sądów rejonowych nie radziły sobie z terminowym rozpatrywaniem spraw o wykroczenia w postępowaniu zwyczajnym, stąd ustawodawca nadał temu przewidującemu rozprawę trybowi charakter wyjątkowy ${ }^{72}$.

W obowiązującym stanie prawnym rozstrzyganie spraw o wykroczenia odbywa się przede wszystkim w trybie postępowania nakazowego, czemu sprzyja bardzo elastyczne sformułowanie przesłanek dopuszczalności stosowania tego trybu. Są nimi niebudzące wątpliwości okoliczności popełnienia czynu i wina obwinionego. Wydając wyrok nakazowy sędzia nie widzi obwinionego ani pokrzywdzonego, opierając wydane rozstrzygnięcie na dołączonych do wniosku o ukaranie ustaleniach poczynionych w trakcie czynności wyjaśniających. Niechętne podejście sędziów do rozstrzygania spraw o wykroczenia na rozprawie skutkuje powszechnym traktowaniem dostarczonych przez policję dowodów jako $\mathrm{w}$ pełni uzasadniających przeprowadzenie postępowania nakazowego ${ }^{73}$. Dopiero wniesienie sprzeciwu od wyroku nakazowego skutkuje rozstrzygnięciem sprawy w trybie postępowania zwyczajnego, aczkolwiek mankamentem tego trybu jest fakt prowadzenia rozprawy przez jednoosobowy skład sędziowski ${ }^{74}$. Jeżeli dodamy do tego fakt powszechnego traktowania przez sędziów obowiązku rozstrzygania spraw o wykroczenia w kategoriach zła koniecznego, to bardziej zrozumiała wydaje się tęsknota środowiska sędziowskiego za rozwiązaniami z lat 1990-2001. Z perspektywy historycznej za optymalny należy uznać model zakładający rozstrzyganie spraw o wykroczenia w pierwszej instancji przez posiadające de facto status sądów społecznych kolegia, przy jednoczesnym zapewnieniu kontroli ich orzeczeń przez sądy rejonowe w trybie postępowania przewidującym przeprowadzenie rozprawy.

\section{Bibliografia}

\section{Akty prawne}

Rozporządzenie Prezydenta RP z 22 marca 1928 r. o postępowaniu karno-administracyjnym (Dz. U. nr 38, poz. 365).

Rozporządzenie Prezydenta RP z dnia 11 lipca 1932 r. prawo o wykroczeniach (Dz. U. nr 60, poz. 572).

Ustawa z dnia 15 grudnia 1951 r. o orzecznictwie karno-administracyjnym (Dz. U. nr 66, poz. 154).

Ustawa z dnia 22 maja 1958 r. o zaostrzeniu odpowiedzialności karnej za chuligaństwo (Dz. U. nr 34, poz. 152.).

72 J. Lewiński, Kodeks postępowania w sprawach o wykroczenia. Komentarz, Warszawa 2011, s. 127.

73 A. Mezglewski, Mankamenty postępowania w sprawach o wykroczenia ograniczajace realizację prawa do obrony, „Zeszyty Prawnicze Katolickiego Uniwersytetu Lubelskiego” 2007, nr 2-3, s. 66-67.

74 T. Bojarski, Polskie prawo..., s. 205. 
Ustawa $\mathrm{z}$ dnia 2 grudnia 1958 r. o zmianie ustawy z dnia 15 grudnia 1951 r. o orzecznictwie karno-administracyjnym (Dz. U. nr 77, poz. 396).

Ustawa z dnia 17 czerwca 1966 r. o przekazaniu niektórych drobnych przestępstw jako wykroczeń do orzecznictwa karno-administracyjnego (Dz. U. nr 23, poz. 149).

Ustawa z dnia 20 maja 1971 r. - Kodeks wykroczeń (Dz. U. nr 12, poz. 114).

Ustawa z dnia 20 maja $1971 \mathrm{r}$. - Kodeks postępowania w sprawach o wykroczenia (Dz. U. nr 12, poz. 116).

Ustawa z dnia 20 maja 1971 r. o ustroju kolegiów do spraw wykroczeń (Dz. U. nr 12, poz. 118).

Ustawa z dnia 8 czerwca 1990 r. o zmianie ustaw: Kodeks postępowania karnego, Kodeks postępowania w sprawach o wykroczenia, o ustroju kolegiów do spraw wykroczeń i Kodeks pracy (Dz. U. nr 43, poz. 251).

Ustawa z dnia 2 kwietnia 1997 r. Konstytucja Rzeczypospolitej Polskiej (Dz. U. nr 78, poz. 483).

Ustawa z dnia 22 maja 2003 r. o zmianie ustawy - Kodeks postępowania w sprawach o wykroczenia (Dz. U. nr 109, poz. 1031).

\section{Projekty aktów prawnych}

Prawo o wykroczeniach. Projekt, Warszawa 1970.

\section{Archiwalia}

Archiwum Akt Nowych w Warszawie, Zespół Akt Ministerstwo Sprawiedliwości, sygn. teczki 2010

\section{Monografie}

Bojarski T., Polskie prawo wykroczeń. Zarys wykładu, Warszawa 2012.

Bojarski M., Radecki M., Kodeks wykroczeń. Komentarz, Warszawa 2005

Dąbrowski W. F., Orzecznictwo karno-administracyjne w PRL, Poznań 1967.

Grzegorczyk T., Gubiński A., Prawo wykroczeń, Warszawa 1995.

Jakubowska-Hara J., Grzywna w polskim prawie wykroczeń, Warszawa 2004.

Kasicki G., Wiśniewski A., Kodeks wykroczeń. Kodeks postępowania w sprawach o wykroczenia. Komentarz do noweli z sierpnia 1998 r., Warszawa 1999.

Lewiński J., Kodeks postępowania w sprawach o wykroczenia. Komentarz, Warszawa 2011.

Łysko M., Prace nad kodyfikacja materialnego prawa wykroczeń w Polsce Ludowej (19601971), Białystok 2016.

Marek A., Polskie prawo wykroczeń, Warszawa 1987.

Rajkowski R., Prawo karno-administracyjne Polski Ludowej, Warszawa 1955

Skupiński J., Model polskiego prawa o wykroczeniach, Wrocław - Warszawa - Kraków Gdańsk 1974. 
Szumski J., Środki penalne w polskim prawie wykroczeń na tle doświadczeń praktyki, Lublin 1995.

Świda Z. , Zarys polskiego prawa o wykroczeniach, Wrocław 1995.

Zimmermann M., Art. 72 Konstytucji a dotychczasowe ustawodawstwo polskie, Lwów 1930.

\section{Publikacje w pracach zbiorowych}

Bojarski T., Ewolucja polskiego systemu prawa wykroczeń, [w:] Rozwój polskiego prawa wykroczeń, red. T. Bojarski, M. Mozgawa, J. Szumski, Lublin 1996.

Bojarski T., Zmiany dostosowawcze przepisów prawa wykroczeń do nowych kodeksów karnych, [w:] Rozważania o prawie karnym. Księga pamiątkowa $z$ okazji siedemdziesięciolecia urodzin Profesora Aleksandra Ratajczaka, red. A. Szwarc, Poznań 1999.

Grzegorczyk T., O systemie organów orzekających w sprawach o wykroczenia le lege lata $i$ de lege ferenda, [w:] Rozwój polskiego prawa wykroczeń, red. T. Bojarski, M. Mozgawa, J. Szumski, Lublin 1996.

Łysko M., Kształtowanie polityki karnej w sprawach o wykroczenia przez aparat administracji Polski Ludowej, [w:] Dzieje biurokracji, red. T. Bykowa, A. Górak, J. Legieć, t. VIII, Lublin 2018.

Łysko M., Obwiniony jako uczestnik postępowania w sprawach o wykroczenia - wczoraj i dziś, [w:] Role uczestników postępowań sądowych - wczoraj, dziś, jutro, red. D. Gil, E. Kruk, Lublin 2015.

Łysko M., Socjalistyczna reforma orzecznictwa karno-administracyjnego Polski Ludowej, [w:] Księga pamiątkowa dla uczczenia pamięci Profesor Krystyny Kamińskiej, red. A. Gaca, Toruń 2013.

Marek A., Problemy reformy polskiego prawa wykroczeń, [w:] Problemy odpowiedzialności karnej. Księga pamiątkowa ku czci Profesora Kazimierza Buchały, red. Z. Ćwiąkalski, M. Szewczyk, S. Waltoś, A. Zoll, Kraków 1994.

Marek A., Prawo wykroczeń, [w:] System Prawa Karnego, t. 1, Zagadnienia ogólne, Warszawa 2010.

Szumski J., Chuligański charakter wykroczenia, [w:] Rozwój polskiego prawa wykroczeń, red. T. Bojarski, M. Mozgawa, J. Szumski, Lublin 1996.

Szumski J., Środki karne stosowane wobec sprawców wykroczeń, [w:] Problemy recydywy i drobnej przestępczości w prawie Polski i RFN, red. J. Skupiński, Wrocław 1984.

\section{Artykuły}

Adamiak B., Ewolucja systemu kar w orzecznictwie w sprawie wykroczeń w PRL, „Acta Universitatis Wratislaviensis. Przegląd Prawa i Administracji” 1976, t. VIII .

Bojarski T., Ewolucja polskiego systemu prawa wykroczeń na tle rozwiązań europejskich, "Annales UMCS, Sectio G” 1993, vol. XL.

Gubiński A., Areszt zasadniczy i zastępczy, „Zagadnienia Karno-Administracyjne” 1963, nr 6.

Gubiński A., Ewolucja stosowanych przez kolegia środków karnych i zasad wymiaru kary, „Zagadnienia Wykroczeń" 1977, nr 6. 
Jendrośka J., Rozwój orzecznictwa w sprawach o wykroczenia w Polsce, „Acta Universitatis Wratislaviensis. Przegląd Prawa i Administracji” 1978, t. X.

Jendrośka J., Uwagi o istocie orzecznictwa karno-administracyjnego, „Państwo i Prawo” 1958, z. 2.

Kocel-Krekora Z., Kierunki rozwoju polskiego prawa wykroczeń, „Zagadnienia Wykroczeń" 1987, nr 3.

Łysko M. , Kara pracy poprawczej w orzecznictwie karno-administracyjnym Polski Ludowej, „Miscellanea Historico-Iuridica” 2008, t. VI.

Łysko M., Kształtowanie się ustroju kolegiów orzekających w Polsce Ludowej (1952-1956), „Czasopismo Prawo-Historyczne” 2012, t. LXIV, z. 2,

Łysko M., Przełom roku 1956 w Polsce a orzecznictwo karno-administracyjne, „Zeszyty Prawnicze UKSW" 2011, nr 11.3.

Łysko M., Reforma prawa karno-administracyjnego Polski Ludowej z 1958 r, „Z Dziejów Prawa" 2014, t. 7.

Łysko M., Zasady obsady personalnej kolegiów karno-administracyjnych Polski Ludowej, „Miscellanea Historico-Iuridica” 2013, t. XII.

Mezglewski A., Mankamenty postępowania w sprawach o wykroczenia ograniczajace realizacje prawa do obrony, „Zeszyty Prawnicze Katolickiego Uniwersytetu Lubelskiego" 2007, nr 2-3.

Mirończuk A., Oddziaływanie wychowawcze zakładów pracy, „Zagadnienia Karno-Administracyjne" 1966, nr 5.

Siarkiewicz K., Kształtowanie się ustroju kolegiów, „Zagadnienia Wykroczeń” 1977, nr 4-5.

Siewierski M., Ewolucja postępowania w sprawach o wykroczenia, „Zagadnienia Wykroczeń" 1978, nr 1.

Szumski J., Główne kierunki polityki karnej realizowane przez kolegia do spraw wykroczeń w latach 1972-1989, „Archiwum Kryminologii” 1993, t. XIX.

Walczak S., Niektóre problemy kodyfikacji prawa karnego, „Państwo i Prawo” 1968, nr 4-5.

Zimmermann M., Orzecznictwo karno-administracyjne, „Zagadnienia Karno-Administracyjne" 1965 , nr 4.

\section{Inne pozycje}

Kolegia ds. wykroczeń w PRL (rozwiąania ustawowe i praktyka). Broszura opracowana i wydana staraniem Komisji Interwencji i Praworządności NSZZ „Solidarność" oraz Małopolskiego Komitetu Walki o Praworządność. Warszawa Kraków 1987.

Nowe ustawy o wykroczeniach - narzędziem ochrony porządku publicznego i dyscypliny społecznej, „Zagadnienia Karno-Administracyjne” 1971, nr 3.

O sytuacji w orzecznictwie karno-administracyjnym, „Poradnik dla Kolegiów Orzekających"1960, nr 2.

Wytyczne Ministra Spraw Wewnętrznych w zakresie orzecznictwa karno-administracyjnego na rok 1960, „Poradnik dla Kolegiów Orzekających” 1960, nr 2. 


\section{Streszczenie}

W Polsce międzywojennej wzorem modelu niemieckiego sprawy o wykroczenia poddano orzecznictwu organów administracji państwowej, z jednoczesnym zapewnieniem kontroli sądowej tego orzecznictwa. Po II wojnie światowej na podobieństwo radzieckie powierzono rozstrzyganie spraw o wykroczenia organom kolegialnym orzekającym z udziałem czynnika społecznego. Kolegia zostały podporządkowane administracji spraw wewnętrznych. Nawiązując do wywodzącego się z Austrii modelu administracyjnego, zastąpiono kontrolę sądową odwołaniem do kolegium drugiej instancji. Dokonana po upadku systemu komunistycznego reforma z 1990 r. usytuowała kolegia w strukturach resortu sprawiedliwości w charakterze quasi-sądów społecznych. Orzecznictwo w sprawach o wykroczenia zostało całkowicie poddane kontroli sądowej. Po likwidacji kolegiów w 2001 r. rozstrzyganie spraw o wykroczenia powierzono sądom karnym najniższego szczebla. Współczesny polski model orzecznictwa w sprawach o wykroczenia funkcjonuje na podobieństwo rozwiązań francuskich, lecz w zakresie materialnego prawa wykroczeń nawiązuje do wywodzących się z krajów niemieckich koncepcji administracyjnych.

\section{Summary}

\section{Evolution of the Polish misdemeanour law system in the XX century}

In similarity with German solutions, in the Second Polish Republic (1918-1939) misdemeanour law cases were referred to the jurisdiction of state administration, however, this jurisdiction was subject to judicial review. Later, in the period of the Polish People's Republic, as a product of socialist ideas created in the Soviet Union, the adjudication of petty offence cases was delegated to collective boards with the participation of a social factor. Judicial review was replaced with an appeal procedure to a superior adjudicating board as in the Austrian administrative model, with the adjudicating boards being subordinate to the administration of internal affairs. After the collapse of the Communist regime in 1990, reforms conferred on collective bodies took the form of quasi-public courts. Boards adjudicating petty offences were situated in criminal courts of the lowest level. The consequence of this reform, was the complete submission of adjudicating petty offences to judicial review. In 2001, all collective bodies were liquidated and misdemeanour cases were brought before lowlevel criminal courts. The modern model of Polish jurisdiction on misdemeanour law offences is similar to French solutions, however, material law refers to concepts originating from German countries. 